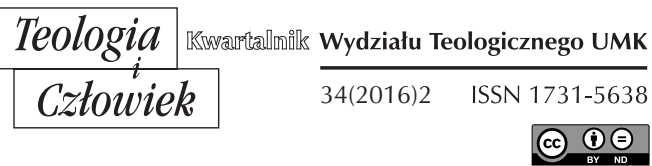

KS. SŁAWOMIR TYKARSKI*

TORUŃ

\title{
ELEMENTY ORGANIZACJI PORADNICTWA - KOMPONENTY PRAKTYCZNE
}

DOI: http://dx.doi.org/10.12775/TiCz.2016.021

W ciągu ostatnich kilkunastu lat można zaobserwować w Polsce rozwój poradnictwa psychologicznego i związane $\mathrm{z}$ nim powstawanie specjalistycznych poradni. Coraz większa grupa osób korzysta $\mathrm{z}$ tego typu usług, z jednej strony ze względu na brak umiejętności poradzenia sobie z problemami, z drugiej zaś ze względu na zwiększoną wyrozumiałość i zmniejszoną dyskredytację społeczeństwa, które przestaje traktować ludzi korzystających z poradni za chorych psychicznie.

Mimo iż poradnictwo można stosować przy różnych okazjach, okolicznościach i miejscach, to jednak o poradnictwie profesjonalnym i o powstaniu poradni mówi się dopiero przy zaistnieniu trzech elementów: osoby doradcy, pomieszczenia i czasu przeznaczonego na działalność poradni ${ }^{1}$. Do tych trzech wyznaczników będzie odnosił się niniejszy ar-

* Ks. Sławomir Tykarski - kapłan diecezji toruńskiej, dr teologii pastoralnej, psychoterapeuta, wykładowca na Wydziale Teologicznym UMK na kierunku nauki o rodzinie. Specjalizuje się w psychoterapii par i małżeństw. Udziela pomocy małżonkom przeżywającym kryzys swojego związku (tykarek@gmail.com).

1 Zob. E. Sujak, Poradnictwo małżeńskie i rodzinne, Katowice 1995, s. 25. 
tykuł. Ze względu na obszerność znaczeniową terminu poradnictwa oraz na wielowątkowość jego organizacji należy wyjaśnić, iż termin „organizacja poradnictwa” obejmuje zarówno czynności i zadania przynależące doradcy, jak również organizację przestrzeni w znaczeniu materialnym działania poradni, co można określić mianem szeroko rozumianego settingu przy pominięciu dyskursu prawno-administracyjnego jej funkcjonowania. W tym znaczeniu i na potrzeby niniejszego artykułu rozumie się organizację poradnictwa.

\section{PIERWSZE SPOTKANIE}

Na ogół pierwsze spotkanie jest bardzo ważne dla klienta. W pewien sposób dokonuje on oceny, czy dany doradca jest w stanie udzielić mu pomocy, czy go rozumie i jest profesjonalistą. Niekiedy osoba szukająca pomocy stresuje się przed pierwszym spotkaniem i odczuwa tremę. Dlatego tak bardzo ważne jest, by doradca wytworzył przyjazną atmosferę spotkania i rozładował emocjonalne napięcie u klienta.

Spotkanie rozpoczyna się od otwarcia drzwi gabinetu i przywitania. Co prawda niektórzy praktycy uważają, iż nie powinno podawać się dłoni podczas powitania, niemniej panuje powszechna opinia, że należy to czynić. Sam sposób podania dłoni może przekazać doradcy pewne informacje. Jeśli uścisk jest mocny, może świadczyć o dominacji bądź zaznaczenia równości. Badania Williama Chaplina wykazują, że mocno ściskają dłoń ekstrawertycy, osoby nieśmiałe i neurotycy - odwrotnie ${ }^{2}$. Jeśli dłoń jest wilgotna, można się domyślać, że klient się stresuje.

Podczas przywitania mile widziane jest przedstawienie się z imienia i nazwiska. Otwarciem rozmowy może być postawienia pytania, czy zgłaszający się nie miał problemu z trafieniem do poradni. Następnie doradca wskazuje miejsce, które ma zająć klient, lub może pozwolić, by sam dokonał on wyboru w przypadku, gdy doradcy nie czyni to różnicy, gdzie siedzi. Wskazówką dla klienta, które miejsce zajmuje doradca może być pozostawienie notatnika na fotelu lub stoliku od strony miejsca, które jest zajęte.

2 Zob. A. Pease, B. Pease, Mowa ciała, tłum. B. Jóźwiak, Poznań 2012, s. 67. Więcej informacji na temat sposobu witania się zob. tamże, s. 55-88. 
Otwarcie rozmowy można zacząć od podania pewnych reguł obowiązujących w poradni. Dotyczą one czasu trwania sesji, robienia notatek przez doradcę, odpłatności za spotkanie oraz sposobu jego odwołania.

Przeważnie klient nie wie, jak zacząć rozmowę, dlatego pomocą ze strony doradcy jest zadanie pytania: „Co panią/pana sprowadza do poradni?”3. Wówczas osoba zaczyna rozwijać wątek, przedstawiając problem bądź przyczynę skorzystania z pomocy. Jeśli zdarzy się, że klient nie wie, od czego zacząć, można zachęcić go do poruszenia sprawy, która aktualnie przychodzi mu na myśl.

Osobne zagadnienie dotyczy sposobu zwracania się do klienta czy używać formy grzecznościowej, czy mniej oficjalnej tzn. mówić po imieniu? Odpowiedź nie jest jednoznaczna i zależy od konkretnej sytuacji. Biorąc pod uwagę polską kulturę i obyczajowość, mówienie po imieniu może być odebrane jako poufałość, zatem nie jest najlepszym rozwiązaniem na początku procesu poradniczego. Jednakże istnieją doradcy, którzy od samego początku zwracają się do klienta po imieniu, chcąc zaakcentować swobodę relacji. Istnieje wówczas niebezpieczeństwo, że przez takie działanie doradca chce w jakiś sposób zaspokoić własne potrzeby. Jeśli natomiast jest to podejście „swobodne i spontaniczne, które odzwierciedla autentyczną osobowość zaangażowanego w poradnictwo, wówczas prawdopodobnie jest to słuszna postawa. Jeśli jednak jest to nieformalność wymuszona, wówczas może ona być postrzegana przez innych jako coś nie na miejscu, jako postawa błędna" ${ }^{4}$. W związku z tym bezpieczniej będzie, gdy doradca spyta klienta, czy nie będzie mu prze-

3 Inna forma zainicjowania rozmowy może brzmieć: „Sesja trwa pięćdziesiąt minut. Jak pan chciałby wykorzystać ten czas?”. Odmienny sposób rozpoczęcia dialogu przez doradcę, który naturalnie się nasuwa, może przyjąć formę pytania: „W czym mogę pani pomóc?”. Jednakże taki zwrot sugeruje nierównowagę sił - doradca jest tym, który pomaga, klient zaś tym, który korzysta z pomocy. Ponadto taka formuła zakłada, że doradca na pewno jest w stanie udzielić pomocy, co niekoniecznie może pokryć się z rzeczywistością. Na pytanie „W czym mogę pani pomóc?” klient może odpowiedzieć: „A skąd pan wie, że potrafi mi pomóc?”. Aby uniknąć takiej sytuacji, lepiej jest rozpocząć rozmowę od zwrotu: „Co panią/pana sprowadza do poradni?” lub „Od czego chciałaby pani zacząć? Ma pani do wykorzystania pięćdziesiąt minut”.

${ }^{4}$ E. Kennedy, S.C. Charles, Jak pomagać dobra radą. Poradnik, tłum. J. Kołacz, Kraków 2010, s. 119. 
szkadzało zwracanie się do niego po imieniu. Nie ma takiego problemu, gdy klientem jest nastolatek, wówczas zwracanie się do niego w sposób bezpośredni nie będzie stanowić przeszkody. W sytuacji, gdy do poradni zgłasza się młody dorosły, który sam proponuje, by doradca mówił mu po imieniu, wtedy należy rozważyć taką możliwość, sprawdzając czy propozycja klienta nie wynika $\mathrm{z}$ jego zaniżonego poczucia wartości i braku szacunku do samego siebie.

Tworząc podczas sesji atmosferę koncentracji na kliencie i poczucia, że jest on ważny, doradca bezwzględnie winien mieć wyłączony telefon i pod żadnym warunkiem nie powinien prowadzić osobistych rozmów podczas trwania spotkania. Również nie powinien w trakcie sesji wychodzić z gabinetu np. w celu porozumienia się z sekretariatem bądź załatwienia innej sprawy niezwiązanej bezpośrednio z klientem.

\section{PRZEPROWADZENIE WYWIADU}

Zadaniem doradcy na pierwszym spotkaniu jest przeprowadzenie wywiadu, czyli pozyskanie podstawowych informacji o kliencie. Dotyczą one następujących obszarów:

- odnośnie do klienta: imię i nazwisko, wiek, wykształcenie, sytuacja zawodowa (czym się zajmuje), sytuacja życiowa (gdzie mieszka i z kim), sytuacja zdrowotna (choroby, zagrożenia zdrowia i życia, kryzysy, załamania);

- odnośnie do powodu zgłoszenia się do poradni (czas i przestrzeń dla swobodnej wypowiedzi pacjenta): jaki jest powód zgłoszenia, dlaczego właśnie teraz poszukuje pomocy, czy wcześniej korzystał z jakiś form pomocy, jak do tej pory sobie radził, dlaczego wybrał tę poradnię i konkretnego doradcę, motywacja klienta do podjęcia zmiany i pracy nad problemem;

- odnośnie do sytuacji rodzinnej: skład członków rodziny, jakie są relacje z ojcem, matką, rodzeństwem, jakie są relacje między rodzicami, jak wyglądają relacje rówieśnicze, przyjaźnie, znajomości, czy klient założył swoją rodzinę ( $\mathrm{z}$ jakich osób się składa i jak wyglądają relacje), inne ważne osoby dla klienta, jakie osoby z otoczenia mogą udzielić wsparcia; 
- odnośnie do doświadczenia życiowego: jakie miały miejsce ważne wydarzenia w historii życia klienta, trudne doświadczenia, jakie ma schematy poznawcze (przekonania o sobie, innych i życiu), mocne strony klienta;

- odnośnie do systemu wartości: jakie wartości są ważne dla klienta, kwestia wiary, duchowości.

Oczywiście doradca nie trzyma się kurczliwie powyższego schematu i nie tworzy klimatu odpytywania klienta. Większą część informacji pozyskuje w trakcie przedstawiania przez klienta sytuacji życiowej. Dzieje się to zatem w sposób naturalny w klimacie szczerego zainteresowania doradcy życiem opowiadającego. Na wszystkie nurtujące pytania doradca nie musi uzyskać odpowiedzi podczas pierwszego spotkania. Wywiad może rozciągnąć się do trzech pierwszych sesji.

\section{KONTRAKT}

Kontrakt to pisemna bądź usta umowa pomiędzy doradcą a klientem dotycząca celu procesu poradnianego (np. rozwiązanie konkretnego problemu), jak również ustalenie częstotliwości spotkań, czasu trwania poszczególnej sesji (zazwyczaj od 45 do 60 minut), sposobu odwoływania spotkania, formy płatności i jej wysokości ${ }^{5}$. Na początku procesu poradnianego zazwyczaj częstotliwość sesji jest większa (np. raz w tygodniu). Następnie stopniowo częstotliwość słabnie np. do jednego spotkania $\mathrm{w}$ miesiącu. Jest to naturalny proces świadczący o tym, że klient coraz

${ }^{5}$ Niekiedy niezrozumienie u klienta wywołuje fakt uiszczenia honorarium za spotkanie, na które się nie stawił i którego uprzednio nie odwołał. Klient poprzez zapłatę niejako „kupuje” czas doradcy będącego w gotowości do pracy. Doradca nie może ponosić konsekwencji za to, że klient tego czasu nie wykorzystał, a dodatkowo mógł być spożytkowany przez inną osobę, która czeka na wolny termin. Odmienną kwestią jest stawka wynagrodzenia. Zbyt niskie honorarium wpływa często demotywująco na klienta, który nie angażuje swoich wysiłków, by dokonać zmiany swojego egzystencjalnego położenia. Natomiast zbyt wygórowana stawka może utwierdzić klienta w przekonaniu, że to doradca winien zmienić jego sytuację życiową, gdyż otrzymuje wysokie wynagrodzenie. Również aby zbyt nie obciążać swojego budżetu, klient będzie dążył do najszybszego rozwiązania problemu, by zmniejszyć liczbę spotkań, co może obrócić się na jego niekorzyść. Zob. J. Kubitsky, Vademecum psychoterapeuty, Warszawa 2008, s. 73-74. 
lepiej potrafi radzić sobie ze swoimi problemami i nie potrzebuje wsparcia doradcy. W przypadku pomocy parom małżeńskim bądź osobom w związkach wydaje się, że najlepszym pomysłem będą spotkania raz na dwa tygodnie. Czas pomiędzy sesjami jest potrzebny małżonkom do zaaplikowania w swoje życie nowych sposobów zachowań, które zostały opracowane podczas sesji.

Ustalenie kontraktu odgrywa ważną rolę, zabezpiecza bowiem przed ewentualnymi nieporozumieniami oraz pozwala na dokładne określenie oczekiwań klienta i doradcy. Odnośnie do celu procesu poradniczego ważna jest kwestia jego realności. Doradca nie może podejmować się celów, które będą nierealne, np. gdy klient chce być zawsze szczęśliwy lub kiedy klientka pragnie, by mąż ją bardziej kochał. Zadaniem doradcy jest sformułowanie konstruktywnych i osiągalnych celów procesu poradniczego. Cele powinny być więc jasno i konkretnie określone oraz zostać uzgodnione i zaakceptowane przez dwie strony - klienta i doradcę. Ponadto winny być osiągalne w określonym czasie i przestrzeni życiowej klienta ${ }^{6}$.

Osobną kwestią jest zagadnienie związane z zakończeniem procesu poradniczego. Doradcy trudno na pierwszym spotkaniu ustalić termin końcowy i podać liczbę sesji. Na proces poradniany mogą oddziaływać zarówno czynniki pomocne (np. klient był w depresji, bo stracił pracę, a teraz ją otrzymał), jak i niepomocne (np. śmierć kogoś bliskiego, dowiedzenie się o zdradzie współmałżonka), które będą miały realny wpływ na przebieg i czas trwania procesu poradniczego ${ }^{7}$. W związku $\mathrm{z}$ tym przy formułowaniu kontraktu doradca może podać ogólne ramy czasowe trwania procesu pomocowego kilku tygodni bądź miesięcy.

\section{AKTYWNE SŁUCHANIE}

Okazuje się, że zapewnienie klientom możliwości wypowiedzenia się oraz bycie przez doradcę dobrym słuchaczem są najbardziej pomocny-

6 Zob. J.A. Heaton, Podstawy umiejętności terapeutycznych, tłum. J. Bartosik, Gdańsk 2003, s. 78-79. „Słuchanie i umiejętność porozumiewania się należą do najskuteczniejszych form pomagania innym". K. Geldard, D. Geldard, Rozmowa, która pomaga. Podstawowe umiejętności terapeutyczne, tłum. M. Gajdzińska, Gdańsk 2004, s. 12.

${ }^{7}$ Więcej na temat zjawisk pomocnych i niepomocnych w procesie pomagania zob. W. Okla, Poradnictwo terapeutyczne, Lublin 2013, s. 115-133. 
mi aspektami w procesie pomagania ${ }^{8}$. „Celem rozmowy ukierunkowanej na pomoc jest dogłębne zrozumienie tego, co czuje osoba, w jaki sposób przeżywa sytuację, która stanowi problem, jak również określenie kontekstu sytuacji życiowej, w jakiej znajduje się osoba, a także poszukiwanie środków i możliwości rozwiązania trudności"'. Pomocna jest ku temu umiejętność słuchania, która często nosi nazwę „aktywnego słuchania” bądź „słuchania empatycznego". Składają się na nie następujące techniki werbalne doradcy ${ }^{10}$ :

- klaryfikacja, czyli wyjaśnianie - doradca, słuchając wypowiedzi klienta, która nie jest zrozumiała w całości, zadaje pytanie typu: „Czy to znaczy, że...?”;

- parafraza - doradca powtarza to, co usłyszał od klienta;

- werbalizacja - doradca zwraca uwagę na emocje i je nazywa, np. „Czy wówczas czuła się pani zawiedziona?”;

- odzwierciedlenie - reakcja doradcy na wypowiedź klienta; można wyróżnić odzwierciedlenie trafne (np. pochwała klienta poprzez zwroty: „brawo”, „dokładnie tak” za celne spostrzeżenie bądź wyciągnięcie wniosku) oraz nietrafne (np. długa przerwa milczenia doradcy po skończonej wypowiedzi klienta bądź jej przerywanie);

- podsumowanie to zebranie i omówienie pokrótce tematu, do którego odnosiły się wypowiedzi klienta; podsumowanie można stosować pod koniec sesji lub w jej trakcie, gdy określone zagadnienie zostało omówione;

- konfrontacja to wyłapywanie przez doradcę wypowiedzi klienta, które się wykluczają, np. „Wcześniej powiedziała pani, że kocha swojego męża, a teraz mówi, że ma go dosyć”;

8 „Próba 35 klientów wykazujących wcześniej skłonności samobójcze, zapytana o to, co pomogło im w przezwyciężeniu zachowań samobójczych, przyznała «byciu słuchanym» jedną z najwyższych ocen: 4,4 na skali $1-5$ (od $1=$ nieważnie do $5=$ bardzo ważne)". M. Cooper, Efektywność psychoterapii i poradnictwa psychologicznego. Wyniki badań i praktyka kliniczna, tłum. A. Wilkin-Day, Warszawa 2010, s. 195.

9 W. Okla, dz. cyt., s. 167.

${ }^{10}$ Por. B. Okun, Skuteczna pomoc psychologiczna, Warszawa 2002, s. 82-83. O podstawowych umiejętnościach komunikacji w czasie pomocy zob. G. Egan, Kompetentne pomaganie. Model pomocy oparty na procesie rozwiązywania problemów, tłum. J. Gilewicz, E. Lipska, Poznań 2002, s. 101-129. 
- interpretacja to nazwanie przez doradcę tego, co powiedział klient w kategoriach psychologicznych;

- psychoedukacja to działanie doradcy w celu przekazania wiedzy na temat funkcjonowania człowieka w różnych okolicznościach życiowych i warunkach społecznych;

- zadawanie pytań - doradca stosuje różne rodzaje pytań (o fakty, postawy, zachowania, uczucia) w zależności, czy chce pozyskać dokładne informacje odnośnie klienta i jego życia, czy chce poznać jego sferę psychiczną ${ }^{11}$; odnośnie do pierwszego przypadku zadaje pytania zamknięte, np. „Kiedy to się stało?; „Ile miał pan wtedy lat?", „Jak długo to trwało?”; natomiast pytania drugiej kategorii przyjmują formułę otwartą, np. "Jak się pani czuje?”, „Co pan teraz czuje?”, „Co masz na myśli, mówiąc...?”, „Co było najtrudniejsze w tamtej sytuacji?”; przy stawianiu wszelakich pytań doradca musi pamiętać, że nie na wszystkie klient będzie chciał odpowiadać i ma on do tego prawo ${ }^{12}$;

- pamiętanie i powtarzanie przez doradcę treści, które wypowiedział klient na poprzednich sesjach.

W celu stworzenia dobrej rozmowy oprócz aktywnego słuchania doradca musi wykazywać się skupieniem uwagi, koncentracją na rozmówcy, poznaniem sposobu jego rozumowania, zapewnić poczucie akceptacji, nie osądzać intencji, stosować informację zwrotną ${ }^{13}$, by dobrze rozumieć

${ }^{11}$ Według Barbary Okun „na treść poznawczą składają się fakty i słowa przekazu. Treść afektywna może być werbalna lub niewerbalna i zawiera uczucia, postawy i zachowania. Odbiór przekazów werbalnych polega na zrozumieniu zarówno treści poznawczych, jak i afektywnych oraz umiejętności ich rozróżnienia. Treść poznawczą zwykle łatwiej zrozumieć, gdyż jest wypowiedziana. Treść afektywna bywa odmienna od poznawczej i często jest mniej oczywista. Różnica między słuchaniem tylko jawnej treści poznawczej przekazu werbalnego a słuchaniem zarówno przekazu poznawczego, jak i leżącego u jego podłoża przekazu afektywnego to różnica pomiędzy pomaganiem nieskutecznym i skutecznym”. B. Okun, dz. cyt., s. 61-62.

12 Zob. J. Milner, P.O’Byrne, Poradnictwo krótkoterminowe: narracje i rozwiązania, tłum. M. Trojański, Poznań 2007, s. 80.

${ }^{13}$ Rogers podaje pięć postaw doradcy związanych $\mathrm{z}$ udzieleniem informacji zwrotnej. Są nimi: ocenianie postępowania klienta (pozytywne-negatywne, dobre-złe), interpretacja (wyjaśnienie, co znaczy problem klienta), sondowanie i badanie (zbieranie jak najwięcej informacji), podtrzymywanie (udzielanie wsparcia, uspokajanie), rozumienie 
klienta, proponować, ale nie dawać konkretnych wskazówek i pomysłów na rozwiązanie problemu.

Należy podkreślić, że język doradcy nie powinien odbiegać od poziomu wypowiedzi klienta. Doradca ma się wystrzegać używania wyrazów, sformułowań i terminów przekraczających możliwość percepcyjne i intelektualne słuchacza. Poziom językowy ma być dostosowany do osoby korzystającej z pomocy. Używanie kwiecistego języka, skomplikowanego i fachowego słownictwa przeszkodzi w budowaniu poczucia zaufania klient przez fakt braku zrozumienia, co doradca komunikuje, może poczuć się przez niego nierozumiany. Ponadto doradca ma mówić bezpośrednio do klienta, a nie o nim, wypowiadać komunikaty typu „ja”, zaznaczając, że są to jego osobiste spostrzeżenie i uwagi, z którymi nie musi godzić się klient.

Aktywne słuchanie nie polega wyłącznie na skupieniu się na przekazach werbalnych. Również czujność nastawiona na komunikację niewerbalną odgrywa niemałą rolę w rozumieniu osoby zgłaszającej się po pomoc. Pozycja ciała (napięta, pochylona, zrelaksowana), kontakt wzrokowy (stały, zmienny lub jego brak), ekspresja mimiczna (ożywiona, uboga), głos (jego siła i tembr, sposób mówienia: szybki, wolny), ogólny wygląd (zadbany, schludny, niechlujny), to elementy, na które winien zwrócić uwagę pomagający i wykorzystać je przy budowaniu relacji oraz w zrozumieniu osobowości i problemu klienta.

\section{SPORZĄDZANIE DOKUMENTACJI}

Pracownik poradni jest zobowiązany do sporządzania dokumentacji. Ma ona charakter notatek spisanych podczas spotkań z klientem. Prowadzenie notatek pomaga śledzić proces zmian zachodzących w osobie zgłaszającej się do poradni. „Notatki są również miernikiem skuteczności [...] i postępów pacjenta i tym samym przyczyniają się do wzrostu kompe-

(intelektualne i emocjonalne wniknięcie w świat klienta, czyli w jego sferę poznawczą, afektywną i behawioralną). Okazuje się, iż w poradnictwie najbardziej wartościową pod względem terapeutycznym jest postawa rozumiejąca. Zob. W. Okla, dz. cyt., s. 178-179. Zob. też J. Mellibruda, Ja - Ty - My. Psychologiczne możliwości ulepszania kontaktów międzyludzkich, Warszawa 1980, s. 341-344. 
tencji zawodowych [...]. Pozwalają sprawdzić, jak pacjent np. zareagował na określoną interpretację, jakie komentarze i interwencje doprowadziły do zmian, co było dominantą ostatnich spotkań, czy dany problem był już wcześniej poruszany, jak pacjent wypełnił swoje zobowiązania" ${ }^{14}$. Ze względu na to, że pamięć doradcy jest ulotna, notatki pomagają odświeżyć informacje dotyczące klienta. Jest to przydatne zwłaszcza w przypadku, gdy doradca ma sporą liczbę osób zgłaszających się po pomoc, jak również w przypadku ponownego zgłoszenia się klienta do poradni po upływie kilku miesięcy bądź lat. Wówczas doradca może odświeżyć wiadomości dotyczące danej osoby, która wcześniej korzystała z jego pomocy. Notatki nie muszą być obszerne, lecz zwięzłe - powinny zawierać następujące informacje: dane osobowe, opis problemu, sytuację rodzinną, społeczną, wykształcenie, stan zdrowia fizycznego i psychicznego, szczególnie ważne sytuacje życiowe klienta.

Pojawia się pytanie, czy notatki winno się sporządzać w trakcie, czy po spotkaniu. Zależy to od doradcy. Jeśli jest w stanie skupiać uwagę na kliencie i pisać, wówczas nie ma przeciwskazań czynienia tego na bieżąco. Jeśli notatka jest obszerniejsza i zawiera uwagi oraz spostrzeżenia doradcy, to lepiej czynić to po spotkaniu, aby klient nie poczuł się zlekceważony przez doradcę, którego bardziej pochłonie sporządzanie wpisu do notatnika niż patrzenie na klienta i obserwacja jego reakcji niewerbalnych, które mogą umknąć jego uwadze. W celu niepominięcia żadnych szczegółów, o których opowiada klient, doradca może zaproponować nagrywanie sesji na dyktafon, jednakże zawsze musi mieć na to pozwolenie klienta. Należy również pamiętać, że klientowi przysługuje prawo wglądu do notatek, jakie sporządził doradca ${ }^{15}$.

\section{TAJEMNICA ZAWODOWA I WYBRANE ZASADY ETYCZNE}

Dochowanie tajemnicy przez doradcę wynika z etyki zawodowej. Jest to warunek niezbędny do zaistnienia przymierza terapeutycznego. $\mathrm{Na}$ pierwszym spotkaniu doradca informuje klienta o obowiązującej go tajem-

14 J. Kubitsky, Vademecum psychoterapeuty, Warszawa 2008, s. 60.

15 Zob. J. Milner, P. O’Byrne, dz. cyt., s. 83. 
nicy co do treści rozmowy, prowadzonej dokumentacji, a nawet samego faktu korzystania $\mathrm{z}$ pomocy przez daną osobę ${ }^{16}$. W ten sposób doradca stwarza klientowi poczucie bezpieczeństwa i anonimowości. Mimo iż doradcę obowiązuje dyskrecja, to jednak są sytuacje, w których jest on z niej zwolniony. Są nimi: decyzja sądu, planowanie przez klienta poważnego przestępstwa (np. zabójstwo, pobicie, napad), stosowanie przemocy i wykorzystywania nieletnich, konsultacja doradcy $\mathrm{z}$ superwizorem ${ }^{17}$. Oprócz tych przypadków doradcę nie obowiązuje dochowanie tajemnicy zawodowej również wtedy, gdy klient planuje popełnić samobójstwo, a jego dokonanie jest jak najbardziej prawdopodobne (np. osoba podaje sposób odebrania sobie życia, zna datę i miejsce, zebrała przedmioty, które posłużą do popełnienia samobójstwa). W związku z tajemnicą zawodową dokumentacja to powinna być przechowywana w bezpiecznym miejscu, do którego nie będą miały dostępu osoby postronne.

Nawiązując do zasad etycznych, doradcy nie wolno wchodzić w relacje seksualne ze swoimi klientami. Nawet po skończonym procesie poradnianym powinny minąć przynajmniej dwa lata zanim doradca nawiąże znajomość z klientem inną niż zawodową. Niektórzy znawcy zjawiska podają w wątpliwość, czy w ogóle w przyszłości klient i doradca mogą w wejść w związek seksualny. „Doradcy utrzymują, że ktoś, kto raz się do nich zgłosił, już na zawsze pozostaje klientem. [...] Doradca

${ }^{16}$ Nieco inaczej wygląda sytuacja, gdy do poradni zgłasza się osoba niepełnoletnia. Wówczas doradca informuje nastolatka o spoczywającym na nim obowiązku przekazania rodzicom niektórych informacji. Aby zmniejszyć dyskomfort młodego klienta, doradca może zaproponować, aby był on obecny podczas jego rozmowy z rodzicami. W ten sposób młodociany klient nie będzie miał wątpliwości, czy przekazane wiadomości nie uległy zniekształceniu lub czy nie doszło do nadinterpretacji. Więcej na temat dochowywania tajemnicy zob. M. Stepulak, Tajemnica zawodowa psychologa, Lublin 2001.

17 Zob. J. Kubitsky, Vademecum terapeuty rodzinnego, Warszawa 2010, s. 144-145. Por. Kodeks etyczny psychoterapeuty Polskiego Towarzystwa Psychiatrycznego http://psychoterapia.olesnica.pl/files/kodeks.pdf ostatni dostęp 07.02.2016), Kodeks etyki zawodowej psychoterapeuty Polskiej Federacji Psychoterapii (http://www.psychoterapia-polska.org/ kodeks-etyczny-pfp ostatni dostęp 07.02.2016), Kodeks etyczno-zawodowy psychologa Polskiego Towarzystwa Psychologicznego (http://www.ptp.org.pl/modules.php?name$=$ News $\&$ file $=$ article $\&$ sid $=29$ ostatni dostęp 07.02.2016). W przypadku prowadzonej superwizji doradca nie podaje superwizorowi danych personalnych swego klienta, ale przedstawia tylko jego problem. 
tworzy relację terapeutyczną jako człowiek, a nie odgrywana przez niego «rola». [...] nawet po zakończeniu spotkań doradca powinien przez jakiś czas - czasem nawet kilka lat - uważać relację terapeutyczną za otwartą. Nie wolno wówczas przekraczać przyjętych norm etycznych. [...] Klienci czasem wracają, by dokończyć terapię, którą wcześniej uznali za zamkniętą. [...] Z pełnym przekonaniem podkreślamy, że relacje seksualne między partnerami, których dzieli nierównowaga sił, są formą najperfidniejszego nadużycia" 18 .

W swoim działaniu doradca zawsze okazuje szacunek klientom i działa na rzecz ich dobra. W związku z tym nie wolno mu wykorzystywać swojej przewagi w relacjach. Szanuje prawo innych osób do posiadania wartości, poglądów czy postaw odmiennych od jego własnych. Nie może dyskryminować klientów z powodu np. wieku, płci, wykształcenia, światopoglądu czy wyznawanej religii.

Ponadto doradca $\mathrm{w}$ prowadzeniu praktyki winien poruszać się w obrębie obszarów pomocowych, w których jest kompetentny i które nie przekraczają jego wiedzy oraz doświadczenia. Metody i narzędzia, którymi się posługuje, powinny mieć charakter naukowy i korespondować z jak najbardziej aktualnym stanem wiedzy w określonej dziedzinie pomocowej. Doradca powinien również podejmować wysiłek, by podnosić swoje kompetencje i standardy poprzez udział w szkoleniach, kursach, wykładach czy warsztatach. Czynności te uzupełnione przez studium własne literatury fachowej mają przyczynić się do ciągłego podnoszenia kwalifikacji i stanu wiedzy ${ }^{19}$.

Niedopuszczalne jest również wykorzystywanie znajomości bądź umiejętności klienta do osobistych celów doradcy. Mimo zaistnienia realnej sytuacji, w której klient w formie wdzięczności zaoferuje swoje usługi czy znajomości, to doradca zobowiązany jest do odmowy skorzystania $\mathrm{z}$ nich i pozostania na wynagrodzeniu, które klient uiszcza podczas każdorazowego spotkania.

${ }_{18}$ D. Mearns, B. Thorne, Terapia skoncentrowana na osobie, tłum. M. Cierpisz, Kraków 2010, s. 206.

19 Zob. Kodeks etyki zawodowej psychoterapeuty; W. Okla, dz. cyt., s. 98-101. 


\section{WYSTRÓJ GABINETU, POCZEKALNI I FUNKCJONOWANIE SEKRETARIATU}

Gabinet jest miejscem, w którym dokonuje się spotkanie klienta $\mathrm{z}$ doradcą, a także jest to przestrzeń wspólnej pracy nad kwestiami problemowymi. W związku z tym wygląd pomieszczenia winien być przytulny, ale neutralny. Przede wszystkim wyposażenie gabinetu nie ma wyolbrzymiać władzy doradcy np. poprzez zajmowanie miejsca za biurkiem, które może świadczyć o pewnego rodzaju dystansie i „władaniu”20. Siedzi on na takim samym i tak samo wygodnym fotelu, co klient, i na takim samym poziomie (bez podwyższenia) i bez dzielących barier. Fotele winny być ustawione pod lekkim kątem względem siebie w taki sposób, by twarze doradcy i klienta nie były zwrócone dokładnie naprzeciw siebie. Z boku może stać stoliczek, na którym będą mieściły się jednorazowe chusteczki higieniczne, lampka, zegarek. Częstym wystrojem gabinetów są książki umieszczone na regale. Warte rozważeniu jest posiadanie takich publikacji (podręczników, poradników, artykułów), plansz, materiałów ćwiczeniowych, które można by było pożyczyć bądź wręczyć klientowi do osobistej pracy poza sesjami.

Pożyteczne jest też wydzielone miejsce dla dzieci, które mogą przychodzić na sesję wraz z rodzicami. Wówczas przy osobnym stoliku dziecko może rysować bądź się bawić. W tej sytuacji w gabinecie mogą znajdować się kredki i kilka zabawek.

Niewskazane jest umieszczanie osobistych zdjęć doradcy w przestrzeni gabinetu, gdyż mogą one rozpraszać klienta lub być przyczyną acting out ${ }^{21}$. Natomiast drzwi gabinetu powinny być wyciszone, by nie wydostawały się słowa rozmowy na zewnątrz.

${ }^{20}$ Zob. O. Benedyktynowicz, Duszpasterstwo i psychoterapia. Poradnictwo pastoralne $w$ praktyce, Warszawa 2002, s. 51.

${ }^{21} \mathrm{Na}$ przykład doradca ma powieszone na ścianie zdjęcie swojej rodziny bądź osób mu bliskich. Klienta może wówczas zastanawiać, kim są te osoby na zdjęciu, jakie relacje wiążą ich z osobą doradcy. Fotografia stanie się wówczas źródłem dekoncentracji i brakiem skupienia na tym, co się dzieje podczas sesji. Ponadto jeśli osoba przychodzi w depresji po stracie kogoś bliskiego lub po rozpadzie związku, to zdjęcie przedstawiające uśmiechniętą rodzinę może wzmocnić przygnębienie. $\mathrm{Z}$ tego powodu pożyteczniejszy 
Również wystrój poczekalni winien być schludny i nieprzypominający poczekalni lekarskiej. Czekający klienci mogą skorzystać z dostępnych czasopism, aktualnych gazet lub ulotek reklamujących ofertę poradni i jej profil $^{22}$. Na ścianie może wisieć tablica informacyjna $\mathrm{z}$ listą doradców i grafikiem dni, w których przyjmują. Można także rozważyć pomysł puszczania muzyki, by umilić czas osobom czekającym na wizytę, jak również zagłuszyć jakiekolwiek dźwięki wydostające się z gabinetu. W pobliżu poczekalni winna znajdować się toaleta.

Należy pamiętać, że doradca jest na sobie znanym terytorium, klient zaś przeciwnie. Dlatego wystrój gabinetu i poczekalni ma za zadanie stworzenia przyjaznej atmosfery, która pomoże osobom korzystającym z poradni czuć się swobodnie i zmniejszyć stres związany z pierwszym spotkaniem.

Jeśli poradnia zatrudnia sekretarkę (recepcjonistkę), to istotna jest jej postawa wobec klientów. Osoba pracująca w recepcji powinna cechować się dyskrecją, serdecznością, uprzejmością, wykazując klientom, że obecność w poradni nie jest niczym wstydliwym i dyskredytującym ${ }^{23}$. Działaniem mającym praktyczne zastosowanie jest podjęcie kontaktu pracownika sekretariatu z klientami na dzień wcześniej przed wizytą w celu potwierdzenia spotkania. W ten sposób skutecznie wyklucza się możliwość zaistnienia sytuacji, w której z jakiś powodów klient nie stawia się na umówioną sesję.

W poradni, w widocznym miejscu powinna znajdować się informacja na temat dni tygodnia i godzin funkcjonowania oraz numer telefonu. Może to być zarówno telefon stacjonarny, jak i komórkowy. W drugim przypadku sekretarka może mieć go przy sobie - w ten sposób umożliwiony jest łatwiejszy kontakt z poradnią. Oczywiście zależy to od wielkości poradni, zakresu i skali świadczonych usług oraz liczby osób zgłaszają-

będzie brak jakichkolwiek zdjęć osobistych w przestrzeni gabinetu. Inną formą acting out może być chęć zapalenia papierosa czy wypicie herbaty i sprowadzenie w ten sposób spotkania do formy towarzyskiej i ucieknięcia od ważnego tematu rozmowy, dlatego podczas sesji klient nie pali, a doradca nie proponuje żadnego napoju. Zob. E. Sujak, dz. cyt., s. 26.

${ }^{22}$ Zob. W. Szewczyk, Poradnictwo rodzinne dzisiaj - jak je usprawnić?, w: Poradnictwo rodzinne w teorii i praktyce, red. U. Dudziak, G. Koszałka, J. Młyński, Kraków 2013, s. 226.

${ }^{23}$ Zob. D. Mearns, B. Thorne, dz. cyt., s. 153. 
cych się po pomoc. Niemniej „badania amerykańskie wykazały najlepszy rozwój poradnictwa wtedy, gdy poradnia była dostępna codziennie przez cały tydzień, zapewniając przyjęcia każdego zgłaszającego się. Rzadsze terminy działalności ujawniały stopniowy zanik frekwencji. Osoby, które zastają drzwi zamknięte - przeważnie nie zgłaszają się więcej, mimo umieszczonej na tych drzwiach informacji o terminach działalności” ${ }^{24}$.

Informacje dotyczące działania poradni mogą zostać umieszczone na stronie internetowej z podaniem pracujących doradców (bądź innych specjalistów) wraz z opisem ich profesji.

Niniejszy artykuł miał na celu omówienie w ujęciu praktycznym podstawowych elementów organizacji poradnictwa, na które składają się: działania doradcy (m.in. inicjacja pierwszego kontaktu i przeprowadzenie pierwszej sesji, sporządzanie dokumentacji, przestrzeganie zasad etycznych) oraz kwestii dotyczących wystroju gabinetu, poczekalni i funkcjonowanie sekretariatu. Oczywiście publikacja ta stanowi zarys przybliżonej tematyki. Autor zdaje sobie sprawę z faktu niewyczerpania opisywanych zagadnień, jak również z tego, że porusza niekiedy kwestie, które mogą wydawać się mało istotne, np.: sposób witania się, ustawienia foteli w gabinecie itp. Niemniej według psychologicznego prawa zwanego "efektem pierwszego wrażenia" te wszystkie elementy mogą mieć istotne znaczenie podczas początkowego spotkania z klientem i wpłynąć na jakość interakcji między nim a doradç̨, a także na sam proces pomocy ${ }^{25}$. Stąd tak drobiazgowy opis poszczególnych kwestii, z których składa się organizacja poradnictwa.

Streszczenie. Elementy organizacji poradnictwa - komponenty praktyczne. W ciągu ostatnich kilkunastu lat można zaobserwować w Polsce rozwój poradnictwa psychologicznego i związane z nim powstawanie specjalistycznych poradni. Coraz większa grupa osób korzysta $\mathrm{z}$ tego typu usług, z jednej strony ze względu na brak umiejętności poradzenia sobie z problemami, z drugiej zaś ze względu na zwiększoną wyrozumiałość

${ }^{24}$ E. Sujak, dz. cyt., s. 26.

25 Istota wspomnianego efektu polega na tym, że osoba poprzez zauważoną jedną ważną pozytywną lub negatywną właściwość przypisuje to samo zabarwienie emocjonalne innym, niezaobserwowanym jeszcze właściwościom przynależącym do danego obiektu np. nowo zapoznanej osobie posiadającej poczucie humoru obserwator lubiący ludzi wesołych jest skłonny przypisać atrybut bycia dobrym człowiekiem. 
i zmniejszoną dyskredytację społeczeństwa, które przestaje traktować ludzi korzystających z poradni za chorych psychicznie.

Mimo iż poradnictwo można stosować przy różnych okazjach, okolicznościach i miejscach, to jednak o poradnictwie profesjonalnym i o powstaniu poradni mówi się dopiero przy zaistnieniu trzech elementów: osoby doradcy, pomieszczenia i czasu przeznaczonego na działalność poradni. Do tych trzech wyznaczników odnosi się niniejszy artykuł. Opisuje on zarówno działania doradcy (sposób zainicjowania pierwszego spotkania, przeprowadzenie wywiadu, zawarcie kontraktu, sporządzanie dokumentacji, dochowywanie tajemnicy zawodowej i przestrzeganie zasad etycznych), jak również organizację poradni w znaczeniu materialnym (wystrój gabinetu i poczekalni oraz pracę sekretariatu). Artykuł nie obejmuje dyskursu prawno-administracyjnego funkcjonowania poradni.

Słowa klucze: organizacja poradnictwa; poradnictwo; poradnia; doradca; klient; pomoc; porada; wsparcie.

Abstract. Elements of counseling organization-practical components. Over the past several years it can be observed in Poland the development of psychological counseling and the associated formation of specialized clinics. More and more people use this type of service, on the one hand because of the lack of ability to cope with problems, on the other hand, due to the increased understanding and reduced discredit society that ceases to treat people using the clinic for the mentally ill.

Although counseling can be used on various occasions, circumstances and places, however, with guidance of professional and about the creation of clinic says only the existence of three elements: individual advisors, space and time for business counseling. This article is referred by those three indicators. It describes both the activities of advisors (how to initiate the first meeting, interview, the conclusion of the contract, drafting documentation, keeping of professional and ethical principles) as well as the organization of clinics in the material sense (design of office, waiting room and secretary ship). This article does not include the discourse of legal and administrative operation of the clinic.

Key words: organization of counseling; counseling; clinic; consultant; customer; help; advice; support. 